\title{
Top-down impact through a bottom-up mechanism. In situ effects of limpet grazing on growth, light requirements and survival of the eelgrass Zostera marina
}

\author{
Richard C. Zimmerman ${ }^{1, *}$, Diana L. Steller ${ }^{2}$, Donald G. Kohrs ${ }^{1}$, Randall S. Alberte ${ }^{3}$ \\ ${ }^{1}$ Moss Landing Marine Laboratories, 8272 Moss Landing Road, Moss Landing, California 95039, USA \\ ${ }^{2}$ Biology Department, University of California, Santa Cruz, California 95064, USA \\ ${ }^{3}$ Phycogen Inc., Portland, Maine 04104, USA
}

\begin{abstract}
Temporal changes in abundance, size, productivity, resource allocation and light requirements of a subtidal eelgrass (Zostera marina L.) population were followed for $2 \mathrm{yr}$ after the September 1993 appearance of a previously rare oval form of the commensal limpet Tectura depicta (Berry) in Monterey Bay, California, USA. By exclusively targeting the epidermis, limpet grazing impaired photosynthetic performance but left respiratory demand, meristematic growth and more than $90 \%$ of the leaf biomass intact. The resulting low $P: R$ ratios of grazed plants raised the light requirements for the maintenance of positive carbon balance almost 2-fold relative to healthy ungrazed plants and prevented the summertime accumulation of internal carbon reserves. Shoot density in this once-continuously vegetated 30 ha meadow declined from more than 50 shoots $\mathrm{m}^{-2}$ (2230 $\mathrm{g}$ fresh wt $[\mathrm{FW}] \mathrm{m}^{-2}$ ) to sparse patches supporting an average of 16 shoots $\mathrm{m}^{-2}\left(380 \mathrm{~g} \mathrm{FW} \mathrm{m}^{-2}\right)$. More than $50 \%$ of the continuously vegetated meadow was converted to bare sand despite ambient light availability and water temperatures that were favorable for growth of healthy, ungrazed plants. Plant size declined by $50 \%$ and internal sugar reserves declined more than 4 -fold within 6 mo after the appearance of $T$. depicta. Plant losses were most extensive during winter, when internal carbon reserves were minimal. The dramatic decline in eelgrass vigor and abundance reported here, despite a physical environment that was favorable for healthy eelgrass survival, illustrates the amplification of top-down control by this relatively inconspicuous limpet through a feeding mechanism that specifically impairs photosynthesis, a bottom-up process.
\end{abstract}

KEY WORDS: Seagrass · Grazing $\cdot$ Zostera marina $\cdot$ Tectura depicta $\cdot$ Light requirements $\cdot$ Carbon balance $\cdot$ Photosynthesis

\section{INTRODUCTION}

Dramatic regional declines in seagrass populations are frequently attributed to anthropogenic modification of coastal water quality through sediment loading and eutrophication-stimulated blooms of nuisance algae (Orth \& Moore 1983, Dennison 1987, Duarte 1991, Zim-

*E-mail: rzimmer197@aol.com merman et al. 1991, Dennison et al. 1993, Morris \& Tomasko 1993, Dunton 1994, Short \& Wyllie-Echeverria 1996). Seagrass vulnerability to light limitation is caused by fundamentally high light requirements that can be traced to inefficient carbon-concentrating mechanisms for photosynthesis (Duarte 1991, Durako 1993, Zimmerman et al. 1995b, 1997, Beer \& Rehnberg 1997). In contrast to the extensive literature on bottomup controls, grazer-mediated regulation of seagrass productivity has received considerably less attention. 
Large grazers can impact seagrass productivity significantly if released from predation control, but coexist with healthy seagrasses when grazer population checks remain intact (Valentine \& Heck 1991, Heck \& Valentine 1995, Stoner et al. 1995). Herbivory by small invertebrate grazers generally has minimal negative impacts on seagrass growth and biomass in otherwise healthy populations, and may have important positive functions by controlling epiphyte growth and mobilizing seagrass detritus (Howard \& Short 1986, Klumpp et al. 1992, Mazzella et al. 1992, Neckles et al. 1993, 1994, Tunberg et al. 1994, Thom et al. 1995, Nelson \& Waaland 1997, Fong et al. 2000).

Several species of cryptic limpets live commensally on seagrass leaves, and a few graze directly on the leaf epidermis (Barbour \& Radosevich 1979). At low densities, these limpets have negligible effects on seagrass productivity, but extensive grazing of the leaf epidermis can significantly impact productivity, resource allocation and survival of eelgrass (Zimmerman et al.

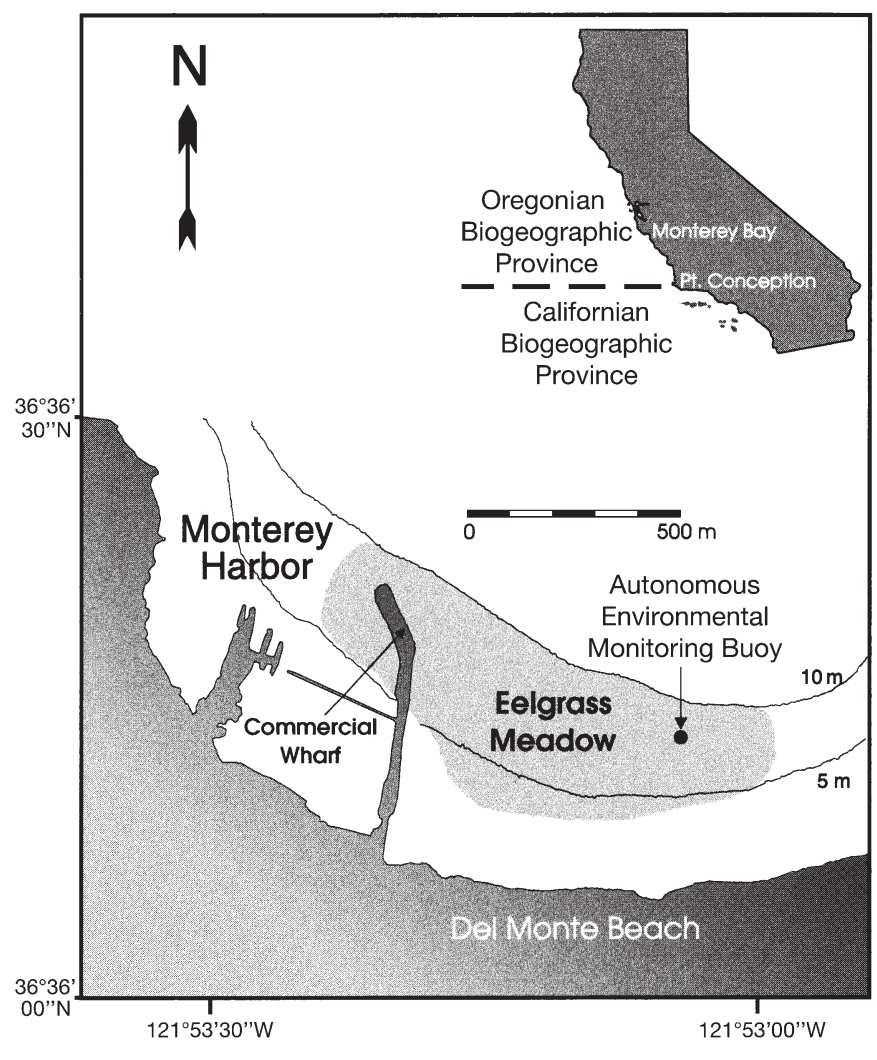

Fig. 1. Marine biogeographic boundary separating Monterey Bay and the Oregonian biogeographic province north of Pt. Conception from the Californian biogeographic province in the south, and the Del Monte Beach study site located in Monterey Bay, California. Zostera marina meadow was located between 3 and $10 \mathrm{~m}$ depth contours just east of Monterey Harbor. Ambient light availability and water temperature were measured continuously by the autonomous environmental monitoring buoy located at the site marked on the map
1996). The previously rare oval form of the commensal acmeid limpet Tectura depicta (Berry) appeared suddenly in high abundance within a subtidal eelgrass (Zostera marina L.) meadow in Monterey Bay, California, USA in September 1993. Prior to our discovery, this oval form was known from fewer than 10 preserved specimens and a few fossil shells collected more than $600 \mathrm{~km}$ to the south near San Pedro, California (Lindberg 1980).

The common laterally compressed 'Zostera form' of Tectura depicta can be found on intertidal populations of eelgrass throughout the Californian biogeographic province south of Pt. Conception, California (see Fig. 1). The laterally compressed form has not, however, been reported from the Oregonian biogeographic province north of Pt. Conception (which includes Monterey Bay) since a warm-water period in the mid 19th century (Lindberg 1980). The rare oval form reported here has never been found north of the Pt. Conception boundary, and its persistence in Monterey Bay may constitute a significant new structuring element in seagrass meadows of northern and central California.

The capacity of ecologically relevant densities of Tectura depicta to impact eelgrass light requirements, productivity and survival has been demonstrated experimentally (Zimmerman et al. 1996). Here we describe the temporal changes in abundance, light requirements, productivity and chemical composition of a subtidal eelgrass population following the appearance of $T$. depicta in Monterey Bay. The dramatic decline in eelgrass vigor and abundance reported here, despite a physical environment that was favorable for eelgrass growth, exemplifies the sometimes subtle mechanisms by which introductions or changes in the abundance of apparently innocuous species can rapidly alter the function of subtidal ecosystems.

\section{MATERIALS AND METHODS}

Study site. Prior to our first observation of Tectura depicta (Berry) in September 1993, eelgrass (Zostera marina) was distributed as a continuous 30 ha meadow along Del Monte Beach at the southern end of Monterey Bay, California, USA (Fig. 1). The shallow limit roughly followed the $3 \mathrm{~m}$ depth contour, and was probably controlled by wave action on this partially exposed coastline. The deep edge was most probably determined by light availability. The meadow was bounded on the west by the Monterey Harbor and on the east by a shale reef that supports a rocky substrate community dominated by the giant kelp Macrocystis pyrifera (L.) C. Agardh. 
The Del Monte Beach eelgrass meadow was separated from the nearest eelgrass population to the north in Elkhorn Slough by $30 \mathrm{~km}$ of wave-swept sandy coast. Genetic analysis revealed restricted gene flow between these eelgrass populations (Alberte et al. 1994). The nearest eelgrass population to the south exists in Morro Bay, which is separated from Del Monte Beach by $180 \mathrm{~km}$ of open rocky coast. No Tectura depicta or grazing scars were found on eelgrass growing in Elkhorn Slough (30 km north), San Francisco Bay (150 km north) Tomales Bay (200 km north) or Morro Bay (180 km south) throughout 1994 and 1995. Prior to the initiation of this study, the eelgrass distribution at Del Monte Beach had been temporally stable and dense (mean shoot density $=50$ shoots $\mathrm{m}^{-2}$, mean leaf area index, LAI, $\cong 2$ ) for more than $10 \mathrm{yr}$ (Zimmerman pers. obs.).

Environmental conditions. Water temperature and light availability were monitored continuously from September 1993 through August 1995 at the Del Monte Beach study site using a moored autonomous buoy (Fig. 1). Temperature and irradiance sensors were deployed from the buoy through the water column and along the sea floor. Submarine scalar irradiance, $E_{0}$ (sub), was measured at the sediment surface (8 $\mathrm{m}$ depth) and $0.5 \mathrm{~m}$ above the bottom with LiCor spherical $(4 \pi)$ quantum sensors calibrated for photosynthetically active radiation (PAR $=400$ to $700 \mathrm{~nm}$ ). The attenuation coefficient of scalar irradiance $\left(K_{\mathrm{o}}\right)$ was calculated from the difference in $E_{0}$ (sub) readings of the 2 submarine sensors according to Beer's law, using only in situ readings taken between 10:00 and 15:00 $\mathrm{h}$ each day to minimize the effect of sun angle (Miller \& McPherson 1995). Downwelling plane irradiance at the sea surface, $E_{\mathrm{d}}$ (air), was measured using a Li-Cor cosine $(2 \pi)$ PAR sensor mounted on the top of the buoy. Water temperature was measured by YSI precision thermistors located at the water surface, $4 \mathrm{~m}$ below the surface, and on the sea floor $(8 \mathrm{~m}$ depth, mean lower low water). All sensors were interrogated every $15 \mathrm{~min}$. Data were stored by an onboard logger and transmitted to a laboratory-based computer via packet radio transceivers every day. The system was powered by batteries charged from a solar panel on the buoy. Submarine irradiance sensors were cleaned manually of fouling and accumulated debris every $2 \mathrm{wk}$. Fouling of the sensors was minimal throughout the course of the study, and had no effects on measured submarine irradiance as determined by comparison of data recorded immediately before and after the sensors were cleaned. (Temporal gaps in the time series of environmental data resulting from occasional sensor failure are indicated by breaks in the time series plots in Figs 2 \& 12B.)
Eelgrass population density. Eelgrass density was determined periodically along a $30 \mathrm{~m}$ transect at $8 \mathrm{~m}$ depth in the center of what was initially a dense continuous meadow ( 50 shoots $\mathrm{m}^{-2}, \mathrm{LAI} \cong 2$ ). A meter tape was deployed roughly parallel to the $8 \mathrm{~m}$ isobath by SCUBA divers using a compass heading of $270^{\circ}$ magnetic beginning near the bottom-mounted sensor array. Shoot densities within $0.20 \mathrm{~m}^{2}$ quadrats were determined every $2 \mathrm{~m}$ along the transect. The meter tape was retrieved at the end of each survey to prevent mechanical damage of the eelgrass population that might result from a permanently installed line. Successive shoot-density quadrats did not re-sample the same plot as deployment of the transect was not identical each time.

Size of surviving eelgrass patches was assessed by SCUBA divers in April 1995 after extensive fragmentation of the meadow. Ten $100 \mathrm{~m}$ long transects running in a north-south direction parallel to the depth gradient were laid $50 \mathrm{~m}$ apart between the Municipal Wharf and the moored autonomous buoy (range = 3 to $8 \mathrm{~m}$ ) (Fig. 1). Presence or absence of eelgrass was assessed at stations every $10 \mathrm{~m}$ along each transect. Percent cover was calculated from the fraction of the 110 stations (11 per transect) containing eelgrass. Shoot density was determined by counting all shoots within 2 haphazardly placed $0.38 \mathrm{~m}^{2}$ quadrats within each patch. For stations containing eelgrass, elliptical patch areas were calculated from measures of the longest axis across each patch and the axis normal to it.

Eelgrass and limpet morphometrics. Each month, 20 shoots were haphazardly selected for determination of (1) growth rates, (2) biomass allocation among shoots, roots and rhizomes, (3) carbon reserves, (4) metabolic performance and (5) light requirements. The leaf sheath of each shoot was punched with a 20 gauge hypodermic needle. A length of surveyors' flagging tape buoyed by a plastic vial was tied around the rhizome. Tagged plants were harvested by hand after growing undisturbed for 10 to $14 \mathrm{~d}$. Care was taken to collect each plant in its entirety, including all attached rhizomes and roots. A few plants consisted of 2 or at most 3 shoots during the spring period of vegetative proliferation; most plants, however, consisted of a single shoot with its attached rhizome and roots, which is the typical growth form for eelgrass. Collected plants were transported to the laboratory in seawater-filled coolers.

In the laboratory, plants were divided into shoots, roots, and rhizomes, and rinsed in clean seawater to remove sediment, particularly from the roots. All limpets were removed from each shoot, enumerated and measured (longest shell axis) to the nearest $0.01 \mathrm{~mm}$ using a digital caliper. The divided sections 
were blotted dry and weighed to the nearest mg. Growth rates were determined by measuring (1) the total length of each leaf on each shoot and (2) the distance from the original punch mark on the outer sheath to the existing hole on each leaf (Zieman \& Wetzel 1980). All leaf material below each punch mark, plus young leaves without punch marks, were considered new growth. Daily growth rates were calculated by dividing the length of new leaf tissue by total leaf length of each shoot and by the number of days since marking (Zimmerman et al. 1995b).

Eelgrass metabolism and chemical composition. Leaf photosynthesis $(P)$ versus irradiance $(E)$ responses were measured polarographically each month in wellstirred, temperature-controlled incubation chambers (5 $\mathrm{ml}$ vol.) using sections cut $10 \mathrm{~cm}$ below the tip of the mature leaf \#3 (youngest = \#1) from 10 of the harvested plants. By selecting a fixed distance below the tip of this mature but non-senescent leaf, tissue samples were not biased by arbitrary selection of samples based on the degree of leaf grazing. Ten irradiances between 3 and $500 \mu \mathrm{mol}$ quanta $\mathrm{m}^{-2} \mathrm{~s}^{-1}$ were provided by slide projectors and neutral-density filters. A circulating water bath held the incubation chambers at the mean temperature recorded in situ over the previous 30 d. $P$ versus $E$ data were fit to the exponential function of Webb et al. (1974) using a nonlinear direct-fit procedure and error-estimation routine (Zimmerman et al. 1987). Respiration $(R)$ of each leaf section was measured in the dark in $100 \%$ airsaturated seawater. Root $R$ was measured at an initial $\left[\mathrm{O}_{2}\right]$ of $200 \%$ air saturation to maximize aerobic metabolism (Zimmerman et al. 1989). Leaves were homogenized on ice in $90 \%$ (v/v) acetone to extract chlorophylls $a$ and $b$ after measuring $P$ and $R$. Homogenates were centrifuged and pigment content of each supernatant was quantified spectrophotometrically using the extinction coefficients of Jeffrey \& Humphrey (1975). Sugar content of leaves, roots and rhizomes was measured on $80 \%$ ethanol extracts using a resorcinol assay standardized against sucrose (Zimmerman et al. 1995a).

Whole-plant carbon budgets. In situ periods of irradiance-saturated photosynthesis $\left(H_{\text {sat }}\right)$ were determined by numerical integration of daily $E_{\mathrm{o}}(\mathrm{sub})$ timeseries using the irradiance saturation parameter $E_{k}$ calculated from the $P$ versus $E$ response curves measured each month (Zimmerman et al. 1994). Daily carbon demand and $H_{\text {sat }}$ requirements were calculated according to Zimmerman et al. (1996, 1997). Physiological rate parameters $\left(P_{\mathrm{m}}, R_{\text {leaf }}, R_{\text {root }}, E_{\mathrm{k}}\right)$ and biomass distribution among shoots, rhizomes and roots necessary to calculate $H_{\text {sat }}$ requirements were taken from the monthly determinations described above. All error terms are reported as standard errors throughout.
Statistical analyses. Regression analysis was employed to evaluate the statistical significance of linear trends in the time series observations and relationships between measured variables. For those variables showing no significant temporal trend by regression, the statistical significance of temporal variations was evaluated using 1-way ANOVA, followed by LSD multiple-comparison tests providing ANOVA $\mathrm{p} \leq 0.05$. Solid lines at equivalent $y$-axis elevations on the corresponding figures were used to indicate statistically identical monthly observations determined by LSD analysis.

\section{RESULTS}

\section{Environmental conditions}

Daily mean temperature within the Zostera marina meadow at $8 \mathrm{~m}$ depth fluctuated seasonally from a low of $10.5^{\circ} \mathrm{C}$ in mid-summer to a high of $15.5^{\circ} \mathrm{C}$ in early October (solid line in Fig. 2A). The water column was essentially isothermal from December to March, but showed evidence of stratification and surface warming from June to September. The maximum temperature difference between surface water and the eelgrass meadow (8 $\mathrm{m}$ depth) was about $5^{\circ} \mathrm{C}$ in July and August. Semi-diurnal thermal oscillations were observed in the $15 \mathrm{~min}$ time-series of temperature at 4 and $8 \mathrm{~m}$ during stratified periods (not shown), and were consistent with tidally-driven internal waves propagated along the thermocline boundary (Zimmerman \& Kremer 1984).

Daily-integrated $E_{\mathrm{d}}$ (air) varied approximately 3-fold seasonally between solstices. Cloud-free irradiances ranged from a winter minimum of $15 \mathrm{~mol}$ quanta $\mathrm{m}^{-2}$ $\mathrm{d}^{-1}$ to a summer peak of 45 mol quanta $\mathrm{m}^{-2} \mathrm{~d}^{-1}$ (open circles in Fig. 2B). Clouds and fog produced variations in daily $E_{\mathrm{d}}$ (air) that were often greater than the seasonal range for cloud-free conditions. Daily $E_{\mathrm{o}}(\mathrm{sub})$ at the depth of the eelgrass meadow $(8 \mathrm{~m})$ ranged seasonally from 0 to $15 \mathrm{~mol}$ quanta $\mathrm{m}^{-2} \mathrm{~d}^{-1}$ (black symbols in Fig. 2B). Variation in water-column optical properties affected the transmission of $E_{\mathrm{d}}(\mathrm{sub})$ to the seagrass canopy, resulting in a poor but statistically significant relationship between $E_{\mathrm{d}}$ (air) and $E_{\mathrm{o}}$ (sub) (Fig. 2B inset, see also Table 2). The scalar attenuation coefficient $\left(K_{\mathrm{o}}\right)$ was highly variable from day to day, ranging from a low of 0.1 to a high of $2.8 \mathrm{~m}^{-1}$ (Fig. 2C). Periods of maximum $K_{\mathrm{o}}$ were often associated with runoff and high wave energy generated by storms during the winter and early spring rainy season. Even in summer, however, $K_{0}$ frequently exceeded $0.5 \mathrm{~m}^{-1}$ and changed by a factor of 2 or 3 within $24 \mathrm{~h}$. 


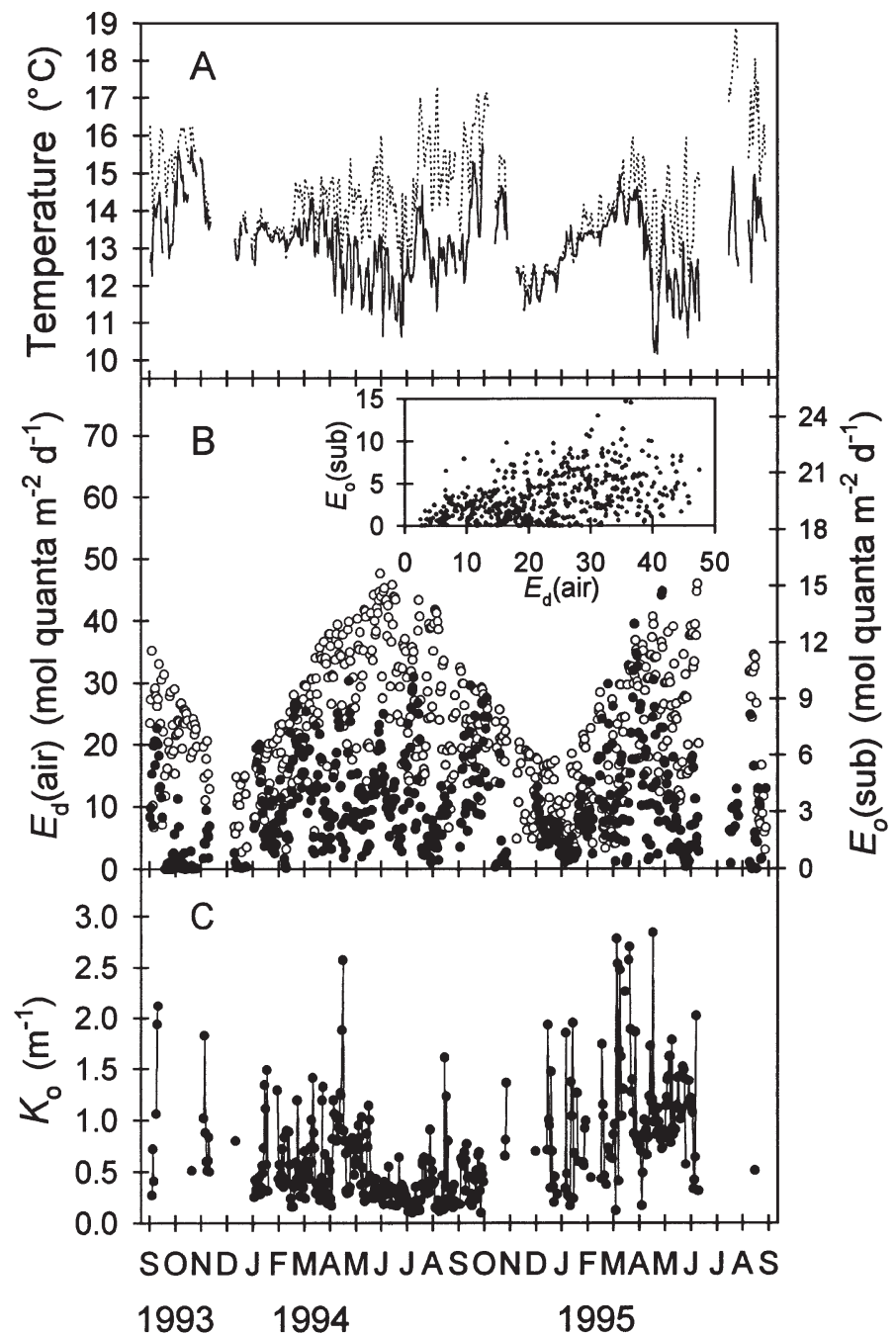

Fig. 2. (A) Time series recordings of mean daily temperature at the surface $(\cdots)$ and within Zostera marina meadow at $8 \mathrm{~m}$ (-). (B) Daily integrated irradiance incident on the sea surface, $E_{\mathrm{d}}($ air) $(0$, left vertical axis), and at the top of the eelgrass canopy, $E_{0}$ (sub) $(\bullet$, right vertical axis); B inset: scatterplot of $E_{\mathrm{o}}$ (sub) versus $E_{\mathrm{d}}$ (air). (C) Mean daily diffuse attenuation coefficient $\left(K_{\mathrm{o}}\right)$

\section{Eelgrass population density and standing crop}

Eelgrass density declined from 50 shoots $\mathrm{m}^{-2}(2230 \mathrm{~g}$ FW $\mathrm{m}^{-2}$ ) in September 1993 to near-extinction by the end of 1994 (Fig. 3A) as the once-continuous and densely vegetated meadow was fragmented into a series of small patches, mostly less than $5 \mathrm{~m}^{2}$ in size (Fig. 3B). More than $36 \%$ of the surviving meadow was reduced to extremely small patches $\left(<2 \mathrm{~m}^{2}\right)$. In total, $56 \%$ of the original meadow was converted to bare sand by 1995 . Eelgrass density averaged $16 \pm 1$ shoots $\mathrm{m}^{-2}$ (380 $\mathrm{g} \mathrm{FW} \mathrm{m}^{-2}$ ) within the surviving patches in April 1995, representing a $70 \%$ reduction in shoot den- sity and an $80 \%$ reduction in area-specific standing crop within the surviving vegetated patches relative to the continuously vegetated meadow in September 1993.

\section{Limpet density and size}

Tectura depicta were first noticed on eelgrass in September 1993, but their density and size were not measured until February 1994. Prior to the appearance of limpets, ungrazed eelgrass leaves were fully green and buoyant (Fig. 4A). Leaves collected beginning in October 1993, however, showed increasing visual evidence of grazing each month, including distinctive grazing scars, pale brown leaves and a lack of leaf buoyancy (Fig. 4B,C). Limpet density averaged more than 5 individuals shoot ${ }^{-1}$ throughout the first half of 1994, but had declined to about 2 individuals shoot ${ }^{-1}$ by August
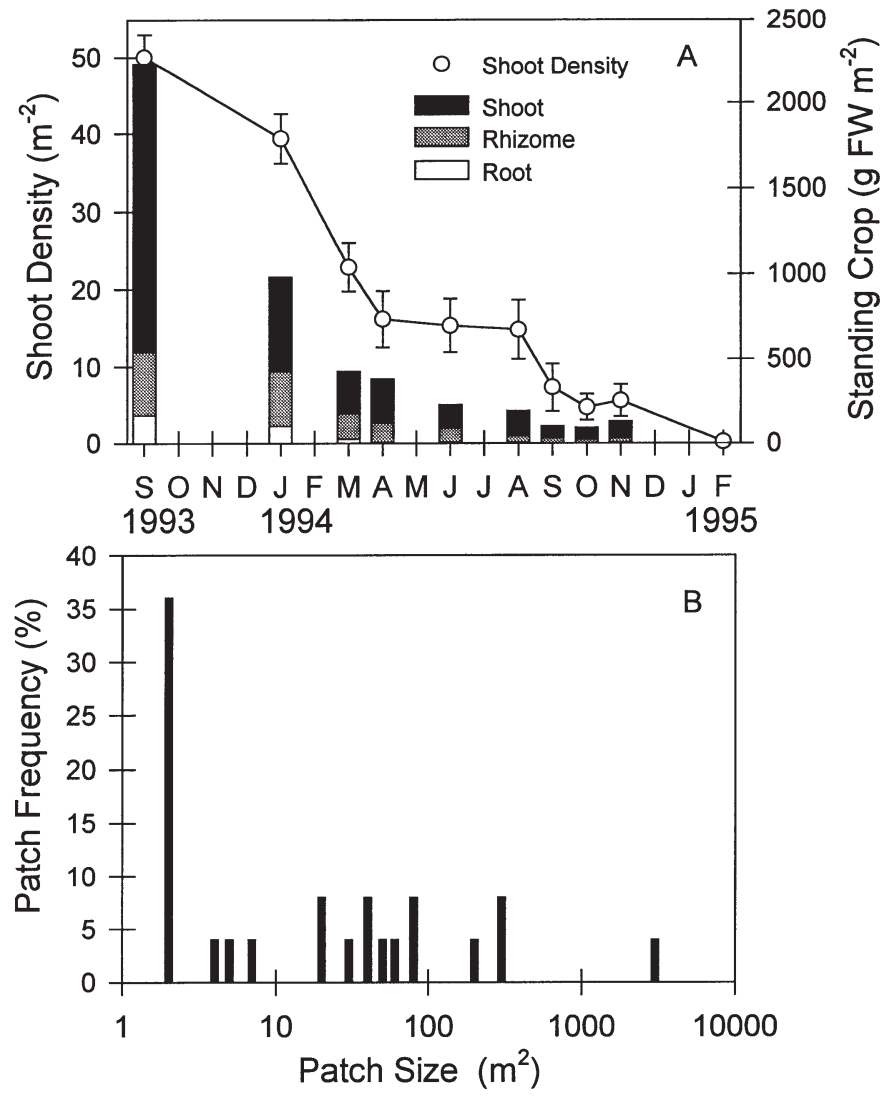

Fig. 3. Zostera marina. (A) Time series of shoot density $(0$, left vertical axis) and standing crop (vertical bars, right vertical axis) from September 1993 until the disappearance of all plants along the permanent transect in February 1995, error bars: \pm 1 SE of the mean for each monthly observation of shoot density. (B) Size-frequency distribution of surviving eelgrass patches measured in spring 1995; shoot density within the surviving patches averaged $16 \pm 1$ shoots $\mathrm{m}^{-2}$. FW: fresh weight 

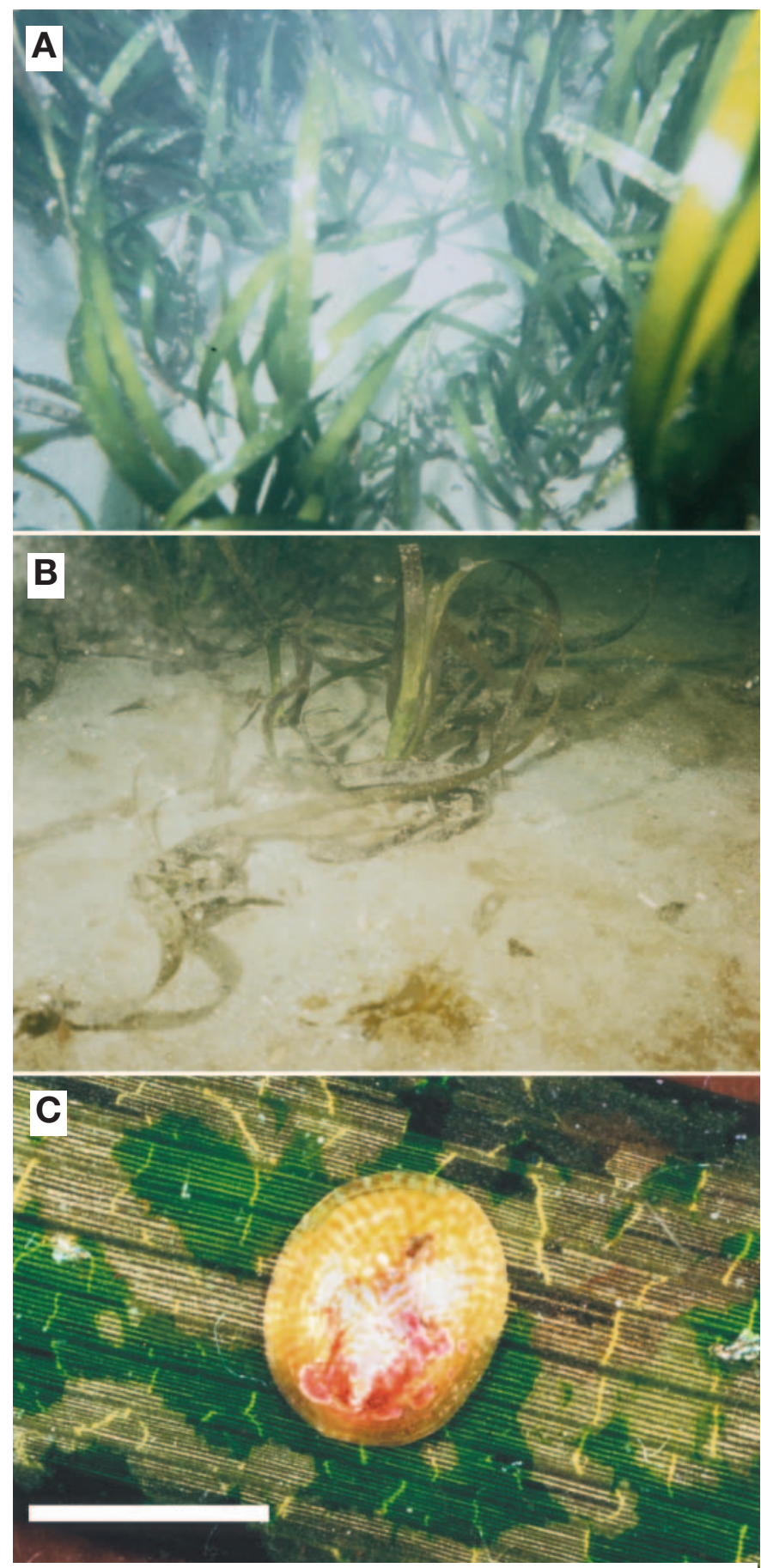

Fig. 4. Zostera marina. (A) Dense eelgrass vegetation in an ungrazed region of the meadow; white spots evident on the older leaves are epiphytes, mostly encrusting bryozoans. (B) An impacted region of the meadow showing a few heavily grazed but surviving eelgrass shoots; brown colored leaves were stripped of chlorophyll by the limpets and lost the buoyancy normally derived from lacunae filled with photosynthetically produced $\mathrm{O}_{2}$. (C) Tectura depicta on an eelgrass leaf illustrating the ungrazed (bright green) and freshly grazed (yellow) regions; lacunae (vein-like striations) and all sub-cuticular cells in the grazed areas remained intact (see Zimmerman et al. 1996) for photomicrograph of a grazed eelgrass leaf in cross-section). White scale bar $=5 \mathrm{~mm}$
1995 (Fig. 5A). Statistically significant peaks in limpet density occurred in spring 1994 and winter 1995 (Table 1, Fig. 5A). Limpet density was lowest during summer months in both 1994 and 1995. In contrast, limpets were larger in summer months than in winter (Table 1, Fig. 5B). The negative relationship between limpet density and size (Table 2) probably resulted from the pulsed settlement of new individuals followed by summer growth and mortality.

\section{Eelgrass growth, biomass allocation and area-specific productivity}

Eelgrass growth rate and size declined dramatically during the fall of 1993, as shoot density declined and limpet grazing became increasingly evident (Table 1, Fig. 6). Size-specific growth rates (Fig. 6A) were consistently higher in summer than winter. Mean plant size decreased significantly from 45 g FW in September 1993 to about 20 g FW in January 1994 and remained around $20 \mathrm{~g} \mathrm{FW}$ for the rest of the study (Fig. 6B). The fraction of biomass allocated to below-ground tissue varied seasonally from a summertime low of about 0.2 to a winter high of about 0.4 (Table 1, Fig. 6C). Although the repeating cycle of size-specific growth rate appeared insensitive to limpet grazing, the combined reductions in plant size and

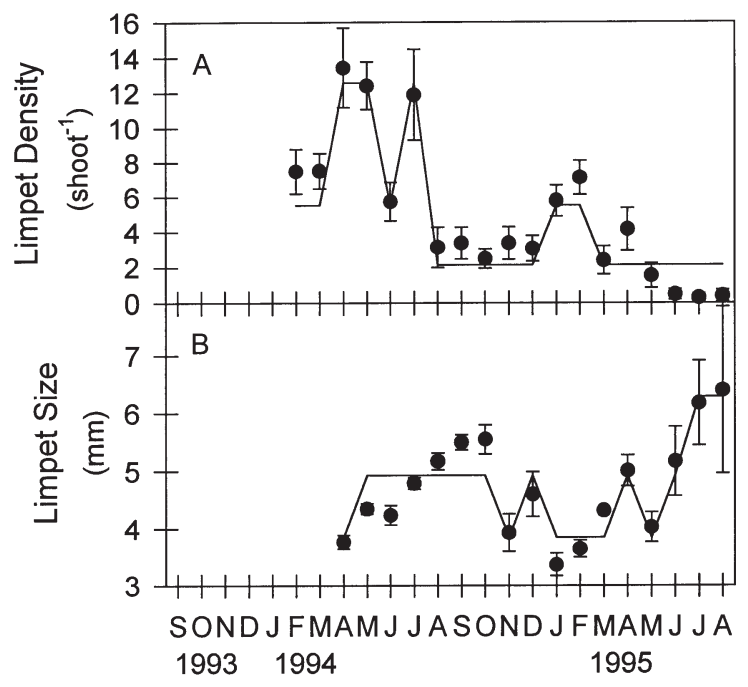

Fig. 5. Tectura depicta. (A) Time series of limpet density on Zostera marina shoots; (B) Limpet size (longest shell axis). Error bars: \pm 1 SE of the mean for each monthly observation. Significant temporal differences among monthly means determined by LSD post-hoc analysis are indicated by different heights of the line running through the data on each plot 
Table 1. Tectura depicta and Zostera marina. ANOVA results for temporal variations in limpet and plant parameters not exhibiting significant monotonic trends. Post-hoc analyses were employed to evaluate specific differences among individual observations when ANOVA revealed statistically significant temporal variation $(p \leq 0.05)$

\begin{tabular}{|c|c|c|c|c|c|c|}
\hline & \multicolumn{2}{|c|}{ Effect } & \multicolumn{2}{|c|}{ Error } & \multirow[t]{2}{*}{$F$} & \multirow[t]{2}{*}{$\mathrm{p}$} \\
\hline & df & MS & $\mathrm{df}$ & MS & & \\
\hline \multicolumn{7}{|l|}{ T. depicta } \\
\hline Density & 18 & 221.07 & 224 & 16.28 & 13.58 & $<0.001$ \\
\hline Limpet size & 16 & 19.72 & 694 & 1.39 & 14.15 & $<0.001$ \\
\hline \multicolumn{7}{|l|}{ Z. marina } \\
\hline Specific growth rate & 21 & 2.59 & 174 & 0.11 & 23.02 & $<0.001$ \\
\hline Size & 23 & 673.48 & 203 & 67.78 & 9.94 & $<0.001$ \\
\hline Arcsine (below-ground biomass fraction) & 23 & 463718.84 & 201 & 442200.63 & 1.05 & 0.04 \\
\hline Leaf respiration & 22 & 0.01 & 202 & 0.00 & 4.34 & $<0.001$ \\
\hline Root respiration & 22 & 0.00 & 143 & 0.00 & 1.08 & 0.38 \\
\hline Chlorophyll $a: b$ & 22 & 0.59 & 198 & 0.06 & 9.63 & $<0.001$ \\
\hline Rhizome internode \#1 sugar & 23 & 13379.92 & 199 & 1541.31 & 8.68 & $<0.001$ \\
\hline Rhizome internode \#3 sugar & 12 & 26525.14 & 115 & 2121.50 & 12.50 & $<0.001$ \\
\hline
\end{tabular}

shoot density lowered area-specific productivity (= shoot density $\times$ plant size $\times$ specific growth) of this meadow by $95 \%$ : from $44 \mathrm{~g} \mathrm{FW} \mathrm{m}^{-2} \mathrm{~d}^{-1}$ in September 1993 to $2 \mathrm{~g}$ FW m ${ }^{-2} \mathrm{~d}^{-1}$ in September 1994. Continued plant losses through August 1995 reduced seagrass production to virtually zero at this site.

\section{Eelgrass metabolism and chemical composition}

The rate of light-saturated gross photosynthesis $\left(P_{\mathrm{m}}\right)$ fluctuated throughout the course of this study between 0.18 and $0.70 \mu \mathrm{mol} \mathrm{O}_{2} \mathrm{~g}^{-1} \mathrm{FW} \mathrm{m^{-1 }}$, and exhibited a statistically significant monotonic increase of $42 \%$ between September 1993 when the limpets were first noticed and August 1995 when limpet density was at its lowest level (Fig. 7A, Table 2). The lowest value of $P_{\mathrm{m}}\left(0.18 \mu \mathrm{mol} \mathrm{O} \mathrm{g}^{-1} \mathrm{FW} \mathrm{min}^{-1}\right)$ was observed in December 1993, when leaves on all plants collected had been heavily grazed. The irradiance required to saturate photosynthesis $\left(E_{k}\right)$ did not show a statistically significant temporal trend, averaging $29 \pm 3 \mu \mathrm{mol}$ quanta $\mathrm{m}^{-2} \mathrm{~s}^{-1}$ throughout the course of this study (regression ANOVA $F[1,21]=1.26, \mathrm{p}=0.27, \mathrm{r}^{2}=0.06$ ) Student's $t$-tests adjusted for multiple comparisons using the Bonferonni correction identified no statistically significant differences between any of the monthly estimates of $E_{k}$ (Bonferonni adjusted $t_{0.05}=5.69$ for 253 comparisons, $18 \mathrm{df})$. Although leaf respiration $\left(R_{\text {leaf }}\right)$ varied from $-0.06 \mu \mathrm{mol} \mathrm{O} \mathrm{g}^{-1} \mathrm{FW} \mathrm{min}{ }^{-1}$ in late summer

Table 2. Tectura depicta and Zostera marina. Linear regression parameters and ANOVA statistics quantifying significant interactions between specific pairs of variables (Ind.: independent; Dep.: dependent). Plots of regressed data can be found in indicated figures $\left(\mathrm{nf}=\right.$ no figure). Numbers in parentheses: standard errors of slopes and intercepts; ${ }^{*} \mathrm{p} \leq 0.05,{ }^{* *} \mathrm{p} \leq 0.01,{ }^{* * *} \mathrm{p} \leq 0.001 . E_{\mathrm{d}}(\mathrm{air})$ : downwelling plane irradiance at the sea surface; $E_{\mathrm{o}}(\mathrm{sub})$ : submarine scalar irradiance; $P_{\mathrm{m}}$ : light-saturated gross photo-synthe-

\begin{tabular}{|c|c|c|c|c|c|c|c|c|}
\hline \multirow[t]{2}{*}{ Fig. } & \multirow[t]{2}{*}{ Ind. variable } & \multirow[t]{2}{*}{ Dep. variable } & \multirow[t]{2}{*}{ Slope } & \multirow[t]{2}{*}{ Intercept } & \multicolumn{4}{|c|}{ Regression ANOVA statistics } \\
\hline & & & & & $\mathrm{r}^{2}$ & $F$ & df & $\mathrm{p}$ \\
\hline 2B (inset) & $E_{\mathrm{d}}($ air $)$ & $E_{\mathrm{o}}(\mathrm{sub})$ & $0.1(0.01)$ & $1.01(0.25)$ & 0.17 & 111.03 & 1,536 & $<0.001^{* *}$ \\
\hline $\mathrm{nf}$ & Limpet density & Limpet size & $-0.10(0.05)$ & $5.18(0.29)$ & 0.24 & 4.65 & 1,15 & $0.047^{*}$ \\
\hline $7 \mathrm{~A}$ & Time & $P_{\mathrm{m}}$ & $0.008(0.003)$ & $0.36(0.04)$ & 0.26 & 7.26 & 1,21 & $0.04^{*}$ \\
\hline $8 \mathrm{~A}$ & Time & Chlorophyll $[a+b]$ & $0.09(0.01)$ & $1.12(0.19)$ & 0.70 & 48.27 & 1,21 & $<0.001^{* * *}$ \\
\hline 9 & Limpet density & Chlorophyll $[a+b]$ & $-0.09(0.03)$ & $3.04(0.19)$ & 0.36 & 9.29 & 1,14 & $0.009^{* *}$ \\
\hline $10 \mathrm{~A}$ & Time & Leaf [sugar] & $2.36(0.35)$ & $12.63(5.27)$ & 0.18 & 46.32 & 1,206 & $<0.001^{* * *}$ \\
\hline 10B & Leaf [sugar] & Absolute growth & $0.0003(0.0003)$ & $0.29(0.02)$ & 0.30 & 80.28 & 1,188 & $<0.001^{* * *}$ \\
\hline nf & Leaf [sugar] & Specific growth & $0.002(0.0008)$ & $1.71(0.06)$ & 0.04 & 7.74 & 1,185 & $0.006^{* *}$ \\
\hline $11 \mathrm{~A}$ & Time & Root [sugar] & $0.57(0.11)$ & $4.19(1.61)$ & 0.12 & 28.59 & 1,205 & $<0.001^{* * *}$ \\
\hline $\mathrm{nf}$ & Leaf [sugar] & Root [sugar] & $0.04(0.01)$ & $10.11(1.02)$ & 0.03 & 6.77 & 1,213 & $0.01^{* *}$ \\
\hline $\mathrm{nf}$ & Leaf [sugar] & Rhizome \#1 [sugar] & $0.27(0.07)$ & $93.43(5.13)$ & 0.06 & 14.3 & 1,217 & $0.002^{* *}$ \\
\hline 11B & Leaf [sugar] & Rhizome \#3 [sugar] & $0.87(0.15)$ & 92.32 (9.46) & 0.72 & 34.62 & 1,124 & $<0.001^{* * *}$ \\
\hline $13 \mathrm{~A}$ & Specific growth & $H_{\text {sat }}$ & $0.16(0.04)$ & $0.53(0.31)$ & 0.48 & 18.56 & 1,20 & $0.003^{* *}$ \\
\hline $13 \mathrm{~B}$ & Limpet density & $H_{\text {sat }}$ requirement & $0.42(0.13)$ & $4.10(0.65)$ & 0.48 & 10.15 & 1,11 & $0.009^{* *}$ \\
\hline
\end{tabular}




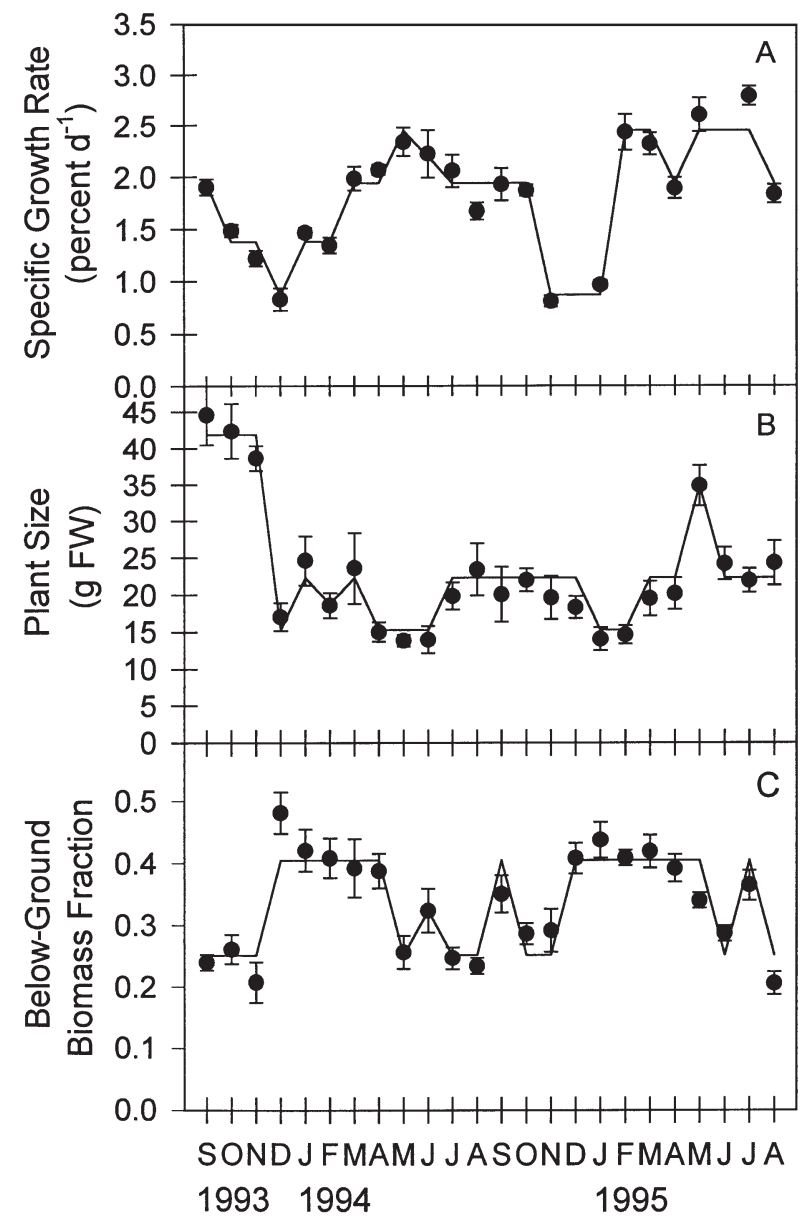

Fig. 6. Zostera marina. (A) Time series of specific growth rates; (B) time series of plant size; (C) time series of below-ground biomass fraction ([root+rhizome]/plant size). Error bars: $\pm 1 \mathrm{SE}$ of the mean for each monthly observation. Significant temporal differences among monthly means determined by LSD post-hoc analysis are indicated by different heights of the line running through the data on each plot

and fall to $-0.10 \mu \mathrm{mol} \mathrm{O}_{2} \mathrm{~g}^{-1} \mathrm{FW} \mathrm{min}^{-1}$ in late winter and spring (Table 1, Fig. 7B), there was no statistically significant monotonic temporal trend in $R_{\text {leaf }}$ (regression ANOVA $F[1,21]=0.10 \mathrm{p}=0.75, \mathrm{r}^{2}=0.005$ ). The mean ratio of instantaneous $P_{\mathrm{m}}: R_{\text {leaf }}$ was $6.3 \pm 0.7$. Rates of biomass-specific root respiration $\left(R_{\text {root }}\right)$ were statistically constant throughout the course of this study (Table 1), averaging $-0.053 \pm 0.004 \mu \mathrm{mol} \mathrm{O}_{2} \mathrm{~g}^{-1} \mathrm{FW}$ $\min ^{-1}$. The mean ratio of $R_{\text {leaf }}: R_{\text {root }}$ was $3.32 \pm 0.48$.

As with $P_{\mathrm{m}}$, leaf chlorophyll $(a+b)$ increased monotonically from a low of $1 \mathrm{mg} \mathrm{g}^{-1} \mathrm{FW}$ in November 1993 to more than $3 \mathrm{mg} \mathrm{g}^{-1} \mathrm{FW}$ by the end of the study (Fig. 8A, Table 2). The chlorophyll $a$ : $b$ ratio oscillated significantly between 1.5 in summer and 2.0 during winter but did not change monotonically as did chlorophyll content (Table 1, Fig. 8B). As might be expected

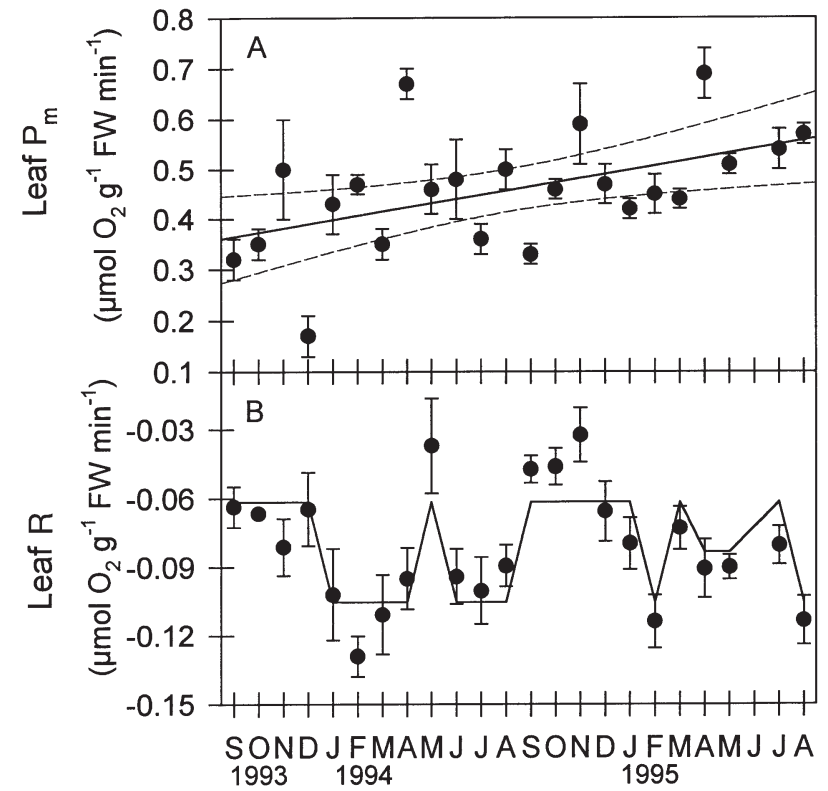

Fig. 7. Zostera marina. (A) Time series of light-saturated gross photosynthesis $\left(P_{\mathrm{m}}\right)$; continuous line indicates statistically significant temporal trend determined by linear regression of $P_{\mathrm{m}}$ versus time; dashed lines indicate $95 \%$ confidence limits of the regression. (B) Leaf respiration measured in the dark; significant temporal differences among monthly means determined by LSD post-hoc analyses are indicated by different heights of the line running through the data. Error bars: $\pm 1 \mathrm{SE}$ of the mean for each monthly observation

from exclusive grazing on the leaf epidermis, limpet density had a significant negative impact on leaf chlorophyll $(a+b)$ content (Fig. 9, Table 2).

Leaf sugar content dropped $95 \%$ from $>200 \mu \mathrm{mol}$ sucrose equiv. $\mathrm{g}^{-1} \mathrm{FW}$ in September 1993 to $10 \mu \mathrm{mol}$ sucrose equiv. $\mathrm{g}^{-1} \mathrm{FW}$ in January 1993 (Fig. 10A). Leaf sugar levels recovered to more than $50 \mu \mathrm{mol}$ sucrose equiv. $\mathrm{g}^{-1} \mathrm{FW}$ by the end of the study, but never again exceeded $100 \mu \mathrm{mol}$ sucrose equiv. $\mathrm{g}^{-1} \mathrm{FW}$. Both absolute and specific growth rates showed a positive relation to leaf sugar content, but regression $\mathrm{r}^{2}$ values indicated a much stronger predictive relationship between absolute growth rates and leaf sugar content (Fig. 10B, Table 2).

Root sugar content tracked the pattern observed for the leaves, declining to its lowest level in November 1993, then rising consistently throughout the rest of the study (Table 1, Fig. 11A: November 1993 to August 1995; Table 2). Similarity in the overall temporal patterns produced a statistically significant correlation between leaf and root sugar even though variations in leaf sugar explained only $3 \%$ of the variation in root sugar (Table 2).

The sugar content of the youngest rhizome internode (\#1) varied significantly throughout the period of the 


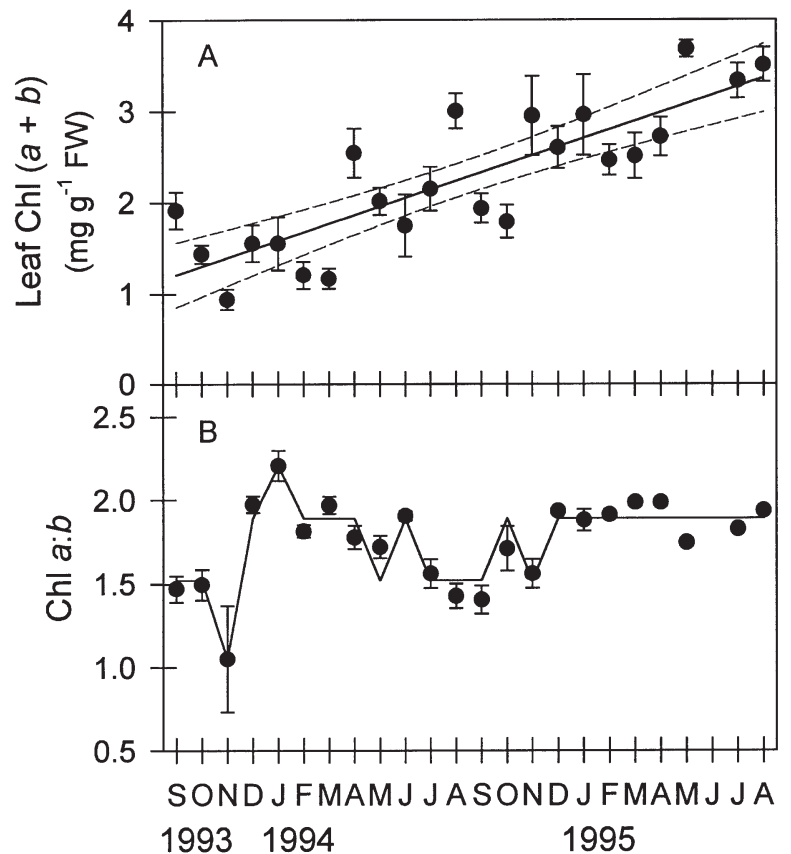

Fig. 8. Zostera marina. (A) Time series of leaf chlorophyll $(a+b)$ content; continuous line indicates statistically significant temporal trend determined by linear regression of chlorophyll $(a+b)$ versus time; dashed lines indicate $95 \%$ confidence limits of the regression. (B) Time series of chlorophyll $a: b$ ratio; significant temporal differences among monthly means determined by LSD post-hoc analyses are indicated by different heights of the line running through the data. Error bars indi-

cate $\pm 1 \mathrm{SE}$ of the mean for each monthly observation

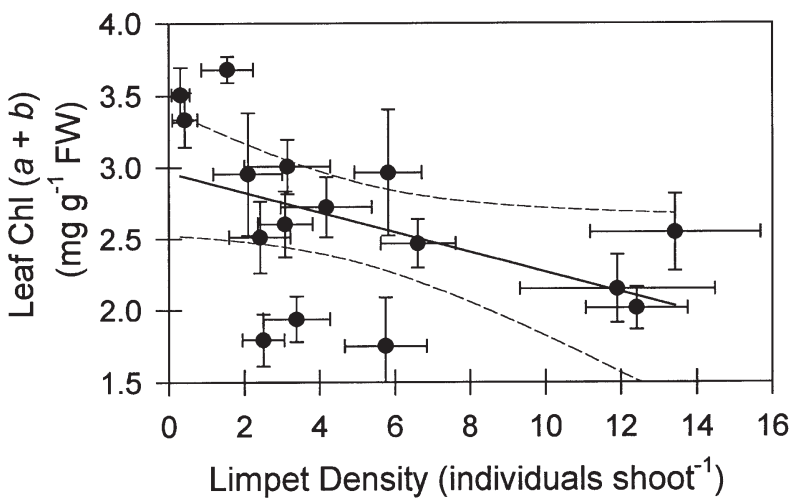

Fig. 9. Zostera marina. Leaf chlorophyll $(a+b)$ content plotted as a function of limpet (Tectura depicta) density. Continuous line indicates statistically significant trend based on linear regression of chlorophyll $(a+b)$ versus limpet density; dashed lines indicate $95 \%$ confidence limits of the regression; error bars: $\pm 1 \mathrm{SE}$ of the mean for each observation

study, but did not exhibit the consistent monotonic trend shown by leaf sugar (Table 1, Fig. 11B). Rhizome Internode \#1 sugar, however, was weakly correlated to leaf sugar content (Table 2). The sugar content of Internode \#3, measured only during the second year of
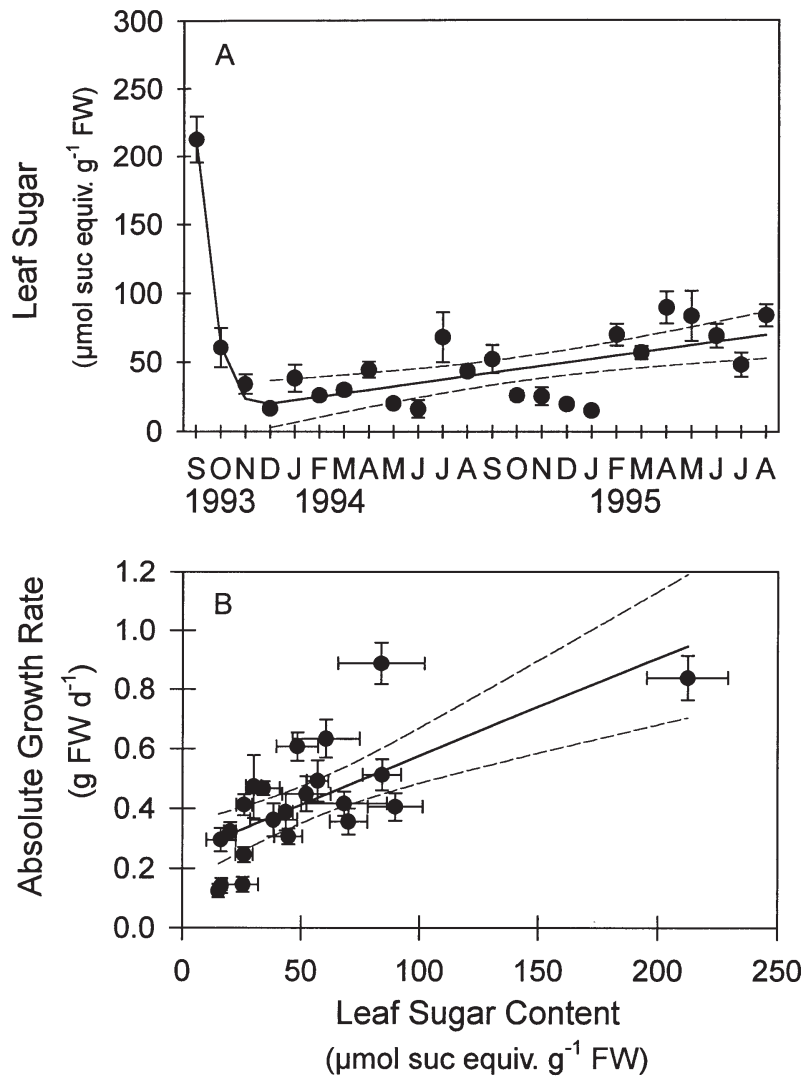

Fig. 10. Zostera marina. (A) Time series of leaf sugar content (sucrose equiv.). Continuous line indicates combination of statistically significant differences in leaf sugar content determined by ANOVA and LSD post-hoc comparisons (September to December 1993) and linear regression of leaf sugar versus time (December 1993 to August 1995); dashed lines indicate $95 \%$ confidence limits of the regression; error bars: $\pm 1 \mathrm{SE}$ of the mean for each observation. (B) Absolute growth rate $(=$ specific growth rate $\times$ plant size) as a function of leaf sugar content; continuous line indicates statistically significant trend based on linear regression of growth versus leaf sugar; dashed lines indicate $95 \%$ confidence limits of the regression; error bars: $\pm 1 \mathrm{SE}$ of the mean for each observation

the study, was consistently higher than the younger Internode \#1 (Table 1, Fig. 11B), and showed a strong positive relationship to leaf sugar content (Fig. 11C, Table 2).

\section{Whole-plant carbon budgets}

The mean monthly $H_{\text {sat }}$ required to maintain positive whole-plant carbon balance ranged from a low of $5 \mathrm{~h}$ to a high of $9.5 \mathrm{~h}$ (Table 1, Fig. 12A: continuous line). The most heavily grazed individuals observed each month required a mean $H_{\text {sat }}$ period of $10 \pm 1 \mathrm{~h}$ to maintain positive carbon balance (open circles in Fig. 12A). Mean monthly $H_{\text {sat }}$ requirements were highest and 


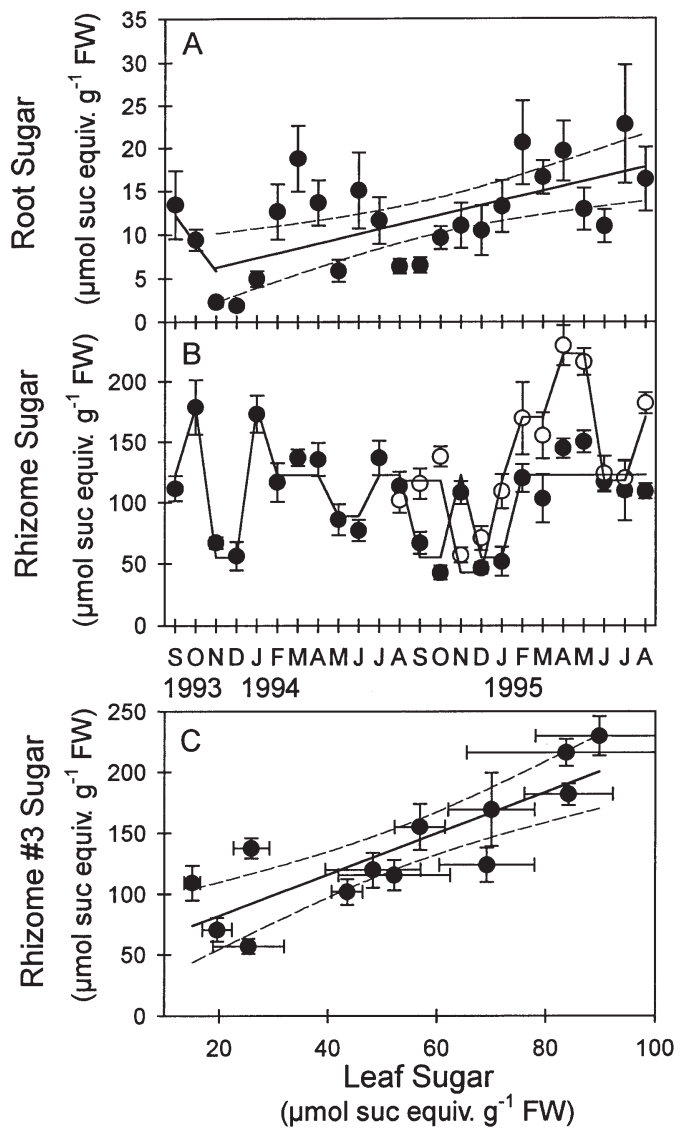

Fig. 11. Zostera marina. (A) Time series of root sugar content; continuous line indicates combination of statistically significant differences in root sugar content determined by ANOVA and LSD post-hoc comparisons (September to December 1993) and linear regression of root sugar versus time (December 1993 to August 1995); dashed lines indicate 95\% confidence limits of the regression; error bars: $\pm 1 \mathrm{SE}$ of the mean for each observation. (B) Time series of rhizome sugar content in internodes \#1 (•, youngest) and \#3 (o); significant temporal differences among monthly means determined by LSD post-hoc analyses are indicated by different heights of the lines running through the data; error bars: $\pm 1 \mathrm{SE}$ of the mean for each monthly observation. (C) Rhizome \#3 sugar content as a function of leaf sugar content; continuous line indicates statistically significant trend based on linear regression of rhizome \#3 sugar versus leaf sugar; dashed lines indicate $95 \%$ confidence limits of the regression; error bars: $\pm 1 \mathrm{SE}$ of the mean for each observation

most variable during the winter of 1993/1994 when limpet densities and rates of eelgrass loss were high but $P_{\mathrm{m}}$, chlorophyll concentrations and growth rates were low. High $H_{\text {sat }}$ requirements also were observed in the winter of 1995, again coincident with a peak in limpet abundance.

Daily $H_{\text {sat }}$ availability ranged seasonally from about $8 \mathrm{~h}$ in the winter to as much as $12 \mathrm{~h}$ in the summer (Fig. 12B). Occasional periods of high $K_{\mathrm{o}}$ (see Fig. 2C) reduced $H_{\text {sat }}$ availability below $4 \mathrm{~h}$ at times throughout the year. Available $H_{\text {sat, }}$ however, exceeded the $4 \mathrm{~h}$ survival threshold for healthy plants more than $80 \%$ of the time and exceeded $8 \mathrm{~h}$ at least $57 \%$ of the time (Fig. 12C). Consequently, light availability was more than adequate to support vigorous growth of ungrazed eelgrass throughout the study period. $H_{\text {sat }}$ periods exceeding $10 \mathrm{~h}$, however, occurred less than $30 \%$ of the time and then only during summer (Fig. 12C). Although summer $H_{\text {sat }}$ periods between 7 and $10 \mathrm{~h}$ may have permitted the maintenance of daily carbon balance, they did not support the accumulation of carbon reserves needed to support growth under winter conditions of low light availability, as indicated by low sugar levels in the leaves throughout 1994 and 1995 that never recovered to the levels observed in September 1993.
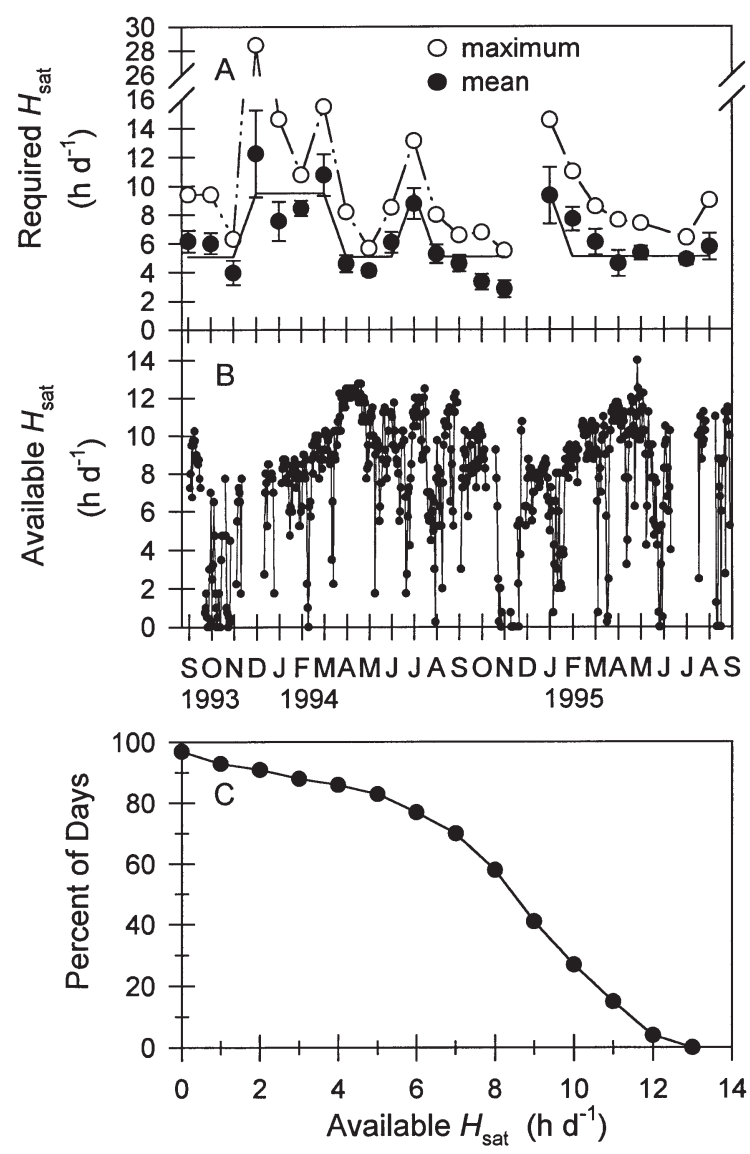

Fig. 12. Zostera marina. (A) Estimates of mean and maximum $H_{\text {sat }}$ (irradiance-saturated photosynthesis) requirements observed each month for whole eelgrass plants, based on calculation of daily carbon balance; significant temporal differences among monthly means determined by LSD post-hoc analyses are indicated by different heights of the solid horizontal line running through the data; error bars: $\pm 1 \mathrm{SE}$ of the mean for each monthly observation. Dot-dashed line was drawn between maximum monthly $H_{\text {sat }}$ requirements. (B) Daily time series of $H_{\text {sat }}$ availability. (C) Frequency distribution of days when measured $H_{\text {sat }}$ met or exceeded threshold $H_{\text {sat }}$ values indicated on the abscissa 

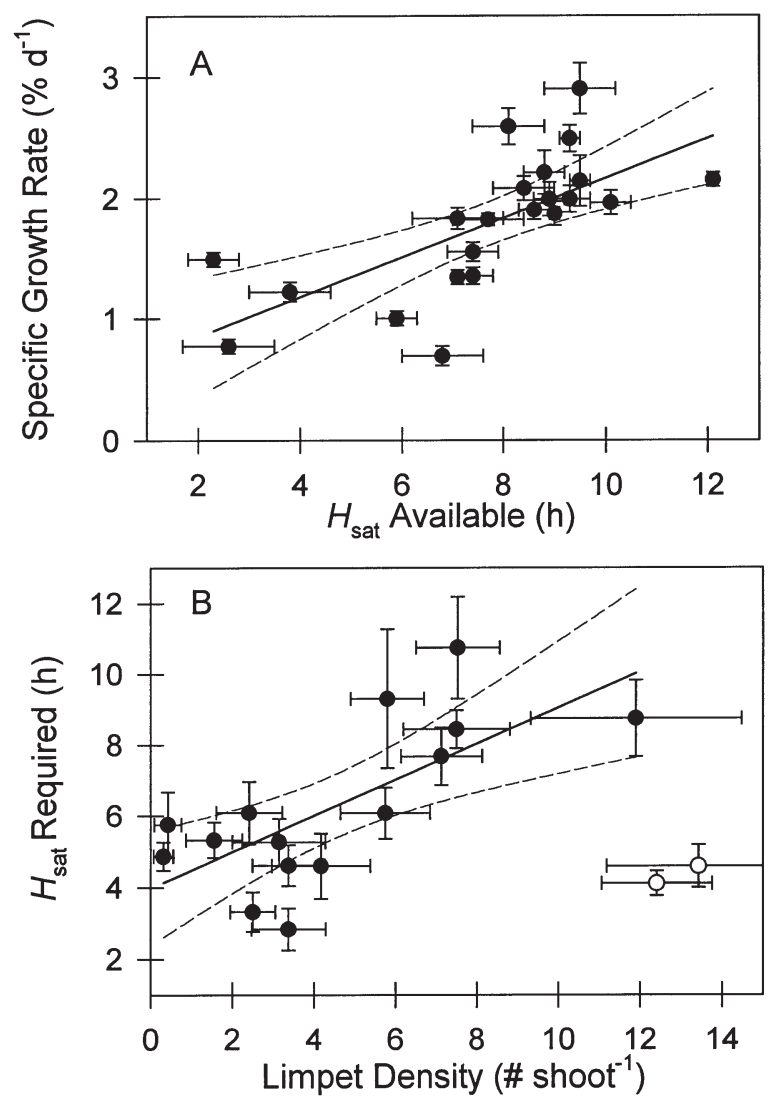

Fig. 13. Zostera marina. (A) Specific growth rates as a function of $H_{\text {sat }}$ availability. (B) Whole plant $H_{\text {sat }}$ requirements plotted as a function of limpet density. Open symbols (O) from April and May 1994 represent collections dominated by very small limpets ( $<4.5 \mathrm{~mm}$ mean length) omitted from the regression analysis. Solid lines indicate statistically significant trends based on linear regression; dashed lines indicate $95 \%$ confidence limits of the regressions; error bars: $\pm 1 \mathrm{SE}$ of the mean for each observation

$H_{\text {sat }}$ availability explained a statistically significant $48 \%$ of the temporal variation in specific growth rates (Fig. 13A, Table 2), which underscores the fundamental light-limited nature of eelgrass production at Del Monte Beach. Eelgrass $H_{\text {sat }}$ requirements, however, were positively related to limpet density (Fig. 13B, Table 2). The $y$-intercept of $4.1 \pm 0.7$ represents the $H_{\text {sat }}$ requirements of ungrazed plants and the slope of the regression line indicates that limpet grazing increased $H_{\text {sat }}$ requirements of this population by $0.4 \pm 0.1 \mathrm{~h}$ limpet $^{-1}$.

\section{DISCUSSION}

In situ dynamics of the Zostera marina population at Del Monte Beach are consistent with our previous results demonstrating that ecologically relevant densi- ties of 5 to 8 Tectura depicta shoot ${ }^{-1}$ severely inhibit growth, productivity and survival of eelgrass through a grazing mechanism that specifically targets the chloroplast-rich epidermis of the eelgrass leaf and impairs photosynthesis (Zimmerman et al. 1996). Leaf respiration rates remained unaffected because less than $10 \%$ of the leaf biomass was consumed by the grazers. The resulting low $P: R$ ratios and high $H_{\text {sat }}$ requirements led to negative carbon balances and consumption of internal carbon reserves by eelgrass in an otherwise light-replete environment during the first 3 mo of this study.

Seagrasses can tolerate considerable levels of grazing by large invertebrates that consume entire leaves when wholesale removal of leaf tissue does not lower $P: R$ ratios of the remaining leaf tissue. Valentine \& Heck (1991) demonstrated that 1 sea urchin $\mathrm{m}^{-2}$ consumed about $10 \%$ of the annual production of Thalassia testudinum (turtlegrass) but had a negligible impact on turtlegrass density and productivity. The limpets observed here consumed similar amounts of biomass, but had a devastating impact on the seagrass meadow. The creation of bare patches in experimental turtlegrass plots required more than 10 urchins $\mathrm{m}^{-2}$ and the consumption of more than $100 \%$ of the annual net production (Valentine \& Heck 1991). Clearly, the impact of limpet grazing on the Del Monte Beach eelgrass population observed in this study was disproportionate to the amount of biomass actually consumed.

Excluding the outbreak of wasting disease in the North Atlantic during the 1930s (Rasmussen 1977), documented losses of most seagrass systems have been related to deteriorated water quality resulting from anthropogenically-increased loading of nutrients and suspended sediments into estuarine and coastal waters which reduced submarine light availability to the benthos (Orth \& Moore 1983, Cambridge \& McComb 1984, Johansson \& Lewis 1992, Dennison et al. 1993, Short \& Wyllie-Echeverria 1996). Seagrass losses observed in this study, however, occurred despite a submarine light environment fully capable of supporting a healthy eelgrass population. The $H_{\text {sat }}$ requirement of $4.1 \mathrm{~h}$ ( $y$-intercept of Fig. 13B) found here for ungrazed eelgrass plants is consistent with previous direct observations of $H_{\text {sat }}$ requirements for ungrazed eelgrass (Dennison \& Alberte 1985, Zimmerman et al. 1989, $1995 b, 1996,1997)$. Furthermore, $H_{\text {sat }}$ availability was consistently above the threshold required for maintenance of healthy ungrazed eelgrass throughout the 2 yr study period. Grazing-induced $H_{\text {sat }}$ requirements exceeding $7 \mathrm{~h}$, however, could be met less than half the time.

The metabolic activity and growth of many seagrass populations exhibit distinct cycles driven by the seasonal pattern in light availability (Sand-Jensen 1975, 
Duarte 1989, Buia et al. 1992, Dunton 1994, Perez \& Romero 1994, Zimmerman et al. 1995b, Herzka \& Dunton 1997). Growth and vegetative proliferation often peak in the spring and early summer, while the accumulation of strategic carbohydrate reserves necessary for winter survival occurs in the late summer and fall. In contrast, in our study, sugar levels in both above- and below-ground tissues increased gradually after the dramatic decline between September and December 1993, but there was little evidence of any seasonality in absolute growth or mobilization/accumulation of sugar reserves. Even though $H_{\text {sat }}$ periods frequently exceeded $10 \mathrm{~h}$ during summer, sugar content never again approached the $200 \mu$ mol sucrose equiv. $\mathrm{g}^{-1} \mathrm{FW}$ found in September 1993, a level typical of photosynthetically competent, light-replete seagrass leaves (Zimmerman et al. 1989, 1996, Dunton 1994, Herzka \& Dunton 1997). There is increasing evidence that carbon reserves accumulated during summer play a decisive role in allowing seagrasses to persist through winter when productivity is reduced by low light availability and/or low water temperatures (Lee \& Dunton 1996, Vermaat \& Verhagen 1996, Alcoverro et al. 1999). Thus, internal consumption of sugar reserves in the fall of 1993 and the inability to accumulate sugar reserves during summer probably potentiated the wintertime eelgrass losses observed here.

Sea-surface temperature was higher than the climatological mean for Monterey Bay during the study period (NOAA CoastWatch El Niño Watch, http:// cwatchwc.ucsd.edu), but well below the $25^{\circ} \mathrm{C}$ threshold required for thermal stress of Zostera marina (Evans et al. 1986, Zimmerman et al. 1989). Thus, direct thermal effects cannot explain the plant losses observed here. Rapid recovery of plant vigor and productivity after experimental removal of limpets from heavily grazed plants (Zimmerman et al. 1996) further undermines the possibility of a temperature effect. Recovery after limpet removal also indicates that pathogenic vectors such as the slime mold Labyrinthula zosterae (Muehlstein et al. 1991) were not responsible for the eelgrass decline at Del Monte Beach.

Although the field observations reported here are qualitatively consistent with our experimental results demonstrating the impact of Tectura depicta on eelgrass productivity (Zimmerman et al. 1996), quantitative effects of limpet density were lower in the natural eelgrass population than in our experiment. Experimentally-sustained densities of 8 limpets shoot ${ }^{-1}$ generated eelgrass $H_{\text {sat }}$ requirements in excess of $13 \mathrm{~h}$ (Zimmerman et al. 1996). In contrast, the regression presented here for field-collected plants generated $H_{\text {sat }}$ requirements of $7.5 \mathrm{~h}$ for similar limpet densities. The difference in $H_{\text {sat }}$ requirements between the experimentally manipulated and naturally grazed plants probably lies with the artificial maintenance of constant limpet density on the experimental plants (Zimmerman et al. 1996). As the experiment progressed, it became increasingly demanding to restrict limpets to the grazed plants as they sought out ungrazed leaves. This movement of unrestrained limpets away from heavily grazed plants may blur the instantaneous relationship between limpet density and eelgrass performance in the field. Nonetheless, the temporal observations and correlations reported here, combined with the experimental results of Zimmerman et al. (1996), provide strong evidence that grazing by high densities of $T$. depicta was primarily responsible for the eelgrass decline observed at Del Monte Beach.

The decline in Tectura depicta abundance from its peak in early 1994 coincided with the extensive destruction of its eelgrass substrate and food source. Furthermore, limpet distributions became increasingly patchy as the eelgrass meadow was fragmented. Although oceanic temperatures along the California coast have been at or below the climatological mean since September 1998 (NOAA CoastWatch El Niño Watch, http://cwatchwc.ucsd.edu), the Del Monte Beach meadow has not recovered as of 2001, and more than $90 \%$ of the habitat now consists of bare sand. High densities of T. depicta can be found in some of the surviving patches, and the plants show visible evidence of grazing, including short stature, brown leaves and low leaf buoyancy (Zimmerman pers. obs.). Other patches are limpet-free; the leaves are green, buoyant and healthy. Persistence of limpets on eelgrass at Del Monte Beach suggests that the once extensive meadow will not recover to its former density if $T$. depicta continues recruiting to newly developing eelgrass patches.

The mechanism(s) controlling the appearance of Tectura depicta and its population dynamics in Monterey Bay remain unknown. The oval form observed here was found recently in low abundance ( 0.1 limpets shoot $^{-1}$ ) in subtidal eelgrass meadows of the Channel Islands south of Pt. Conception in the Californian biogeographic province ( $300 \mathrm{~km}$ south of Monterey Bay) but visible grazing effects were minimal (J. Wible \& J. M. Engle pers. comm.). T. depicta has not been reported from any other eelgrass population in the Oregonian biogeographic province north of Pt. Conception, California, including Elkhorn Slough within Monterey Bay (<30 km N of Del Monte Beach). Thus, T. depicta may have limited dispersal ability, and may have required an anthropogenic vector (e.g. ship ballast: Carlton 1992) and/or warm conditions (e.g. El Niño) to become established at Del Monte Beach. Regardless, this previously rare limpet from southern California now appears to have established a reproductively successful population in Monterey Bay which 
may exclude eelgrass from an otherwise favorable habitat. The power of this relatively inconspicuous limpet to control eelgrass production, density, and distribution represents a dramatic amplification of topdown control by a feeding pattern that limits the bottom-up process of photosynthesis.

Acknowledgements. We thank Teresa Alcoverro and Olga Invers for assistance with field collections and laboratory measurements. James Coyer also assisted with field collections. Henry Chaney provided taxonomic identification of Tectura depicta (Berry). Giacomo Bernardi provided the underwater photograph of grazed eelgrass (Fig. 3B), Lovell and Libby Langstroth provided the close-up photograph of $T$. depicta on a grazed eelgrass leaf (Fig. 3C). The manuscript was improved by constructive comments of 3 anonymous reviewers. Supported by Grant OCE 9223265 from the National Science Foundation.

\section{LITERATURE CITED}

Alberte RS, Suba GK, Procaccini G, Zimmerman RC, Fain SR (1994) Assessment of genetic diversity of seagrass populations using DNA fingerprinting: implications for population stability and management. Proc Natl Acad Sci 91: 1049-1053

Alcoverro T, Zimmerman R, Kohrs D, Alberte R (1999) Resource allocation and sucrose mobilization in light-limited eelgrass (Zostera marina L.). Mar Ecol Prog Ser 187: 121-131

Barbour MG, Radosevich SR (1979) ${ }^{14} \mathrm{C}$ uptake by the marine angiosperm Phyllospadix scouleri. Am J Bot 66:301-306

Beer S, Rehnberg J (1997) The acquisition of inorganic carbon by the seagrass Zostera marina. Aquat Bot 56:277-283

Buia M, Zupo V, Mazzella L (1992) Primary production and growth dynamics in Posidonia oceanica. PSZN I: Mar Ecol 13:2-16

Cambridge ML, McComb AJ (1984) The loss of seagrasses in Cockburn Sound, Western Australia. I. The time course and magnitude of seagrass decline in relation to industrial development. Aquat Bot 20:229-243

Carlton J (1992) Introduced marine and estuarine mollusks of North America: an end-of-the-20th-century perspective. J Shellfish Res 11:489-505

Dennison WC (1987) Effects of light on seagrass photosynthesis, growth and depth distribution. Aquat Bot 27:15-26

Dennison WC, Alberte RS (1985) Role of daily light period in the depth distribution of Zostera marina (eelgrass). Mar Ecol Prog Ser 25:51-61

Dennison WC, Orth RJ, Moore KA, Stevenson JC, Carter V, Kollar S, Bergstrom PW, Batiuk RA (1993) Assessing water quality with submersed aquatic vegetation. Habitat requirements as barometers of Chesapeake Bay health. BioScience 43:86-94

Duarte CM (1989) Temporal biomass variability and production/biomass relationships of seagrass communities. Mar Ecol Prog Ser 51:269-277

Duarte CM (1991) Seagrass depth limits. Aquat Bot 40: 363-377

Dunton K (1994) Seasonal growth and biomass of the subtropical seagrass Halodule wrightii in relation to continuous measurements of underwater irradiance. Mar Biol 120: 479-489

Durako MJ (1993) Photosynthetic utilization of $\mathrm{CO}_{2}$ (aq) and
$\mathrm{HCO}_{3}{ }^{-}$in Thalassia testudinum (Hydrocharitacae). Mar Biol 115:373-380

Evans AS, Webb KL, Penhale PA (1986) Photosynthetic temperature acclimation in two coexisting seagrasses, Zostera marina L. and Ruppia maritima L. Aquat Bot 24:185-197

Fong C, Lee S, Wu R (2000) The effects of epiphytic algae and their grazers on the intertidal seagrass Zostera japonica. Aquat Bot 67:251-261

Heck KL, Valentine JF (1995) Sea urchin herbivory: evidence for long-lasting effects in subtropical seagrass meadows. J Exp Mar Biol Ecol 189:205-217

Herzka S, Dunton K (1997) Seasonal photosynthetic patterns in the seagrass Thalassia testudinum in the western Gulf of Mexico. Mar Ecol Prog Ser 152:103-117

Howard R, Short F (1986) Seagrass growth and survivorship under the influence of epiphyte grazers. Aquat Bot 24 287-302

Jeffrey SW, Humphrey GF (1975) New spectrophotometric equations for the determination of chlorophylls $a, b, c 1$ and c2 in higher plants, algae and natural phytoplankton. Biochem Physiol Pflanzen 167:191-194

Johansson J, Lewis R (1992) Recent improvements of water quality and biological indicators in Hillsboro Bay, a highly impacted subdivision of Tampa Bay, Florida, USA. Sci Total Environ Suppl:1199-1215

Klumpp DW, Salita-Espinosa JS, Fortes MD (1992) The role of epiphytic periphyton and macroinvertebrate grazers in the trophic flux of a tropical seagrass community. Aquat Bot 43:327-349

Lee KS, Dunton K (1996) Production and carbon reserve dynamics of the seagrass Thalassia testudinum in Corpus Christi Bay, Texas, USA. Mar Ecol Prog Ser 143:201-210

Lindberg DR (1980) Notoacmea gabitella (Berry), an outer coast form of Notoacmea depicta (Hinds) (Mollusca: Acmaeidae). Veliger 22:265-272

Mazzella L, Buia MC, Gambi MC, Lorenti M, Russo GF, Scipione MB, Zupo V (1992) Plant-animal trophic relationships in the Posidonia oceanica ecosystem of the Mediterranean Sea: a review. In: John D, Hawkins J, Price J (eds) Plantanimal interactions in the marine benthos. Oxford University Press, Oxford, p 165-187

Miller RL, McPherson BF (1995) Modelling photosynthetically active radiation in water of Tampa Bay, Florida, with emphasis on the geometry of incident irradiance. Estuar Coast Shelf Sci 40:359-377

Morris L, Tomasko D (eds) (1993) Proceedings and conclusions of a workshop on submerged aquatic vegetation and photosynthetically active radiation. St. Johns River Water Management District, Palatka, FL

Muehlstein L, Porter D, Short F (1991) Labyrinthula zosterae sp. nov., the causal agent of the wasting disease of eelgrass, Zostera marina. Mycologia 83:180-191

Neckles HA, Wetzel RL, Orth RJ (1993) Relative effects of nutrient enrichment and grazing on epiphyte-macrophyte (Zostera marina L.) dynamics. Oecologia 36:265-274

Neckles HA, Koepfler ET, Haas LW, Wetzel RL, Orth RJ (1994) Dynamics of epiphytic photoautotrophs and heterotrophs in Zostera marina (eelgrass) microcosms: responses to nutrient enrichment and grazing. Estuaries 17:597-605

Nelson T, Waaland J (1997) Seasonality of eelgrass, epiphyte, and grazer biomass and productivity in subtidal eelgrass meadows subjected to moderate tidal amplitude. Aquat Bot 56:51-74

Orth R, Moore K (1983) Chesapeake Bay: an unprecedented decline in submerged aquatic vegetation. Science 222 $51-53$

Perez M, Romero J (1994) Growth dynamics, production and 
nutrient status of the seagrass Cymodocea nodosa in a Mediterranean semi-estuarine environment. PSZN I: Mar Ecol 15:51-64

Rasmussen E (1977) The wasting disease of eelgrass (Zostera marina) and its effect on environmental factors and fauna. In: Mcroy P, Helferich C (eds) Seagrass ecosystems, a scientific perspective. Marcel Dekker, Inc, New York, p 1-51

Sand-Jensen K (1975) Biomass, net production and growth dynamics in an eelgrass (Zostera marina L.) population in Vellerup Vig, Denmark. Ophelia 14:185-201

Short F, Wyllie-Echeverria S (1996) Natural and humaninduced disturbance of seagrasses. Environ Conserv 23: $17-27$

Stoner A, Ray M, Waite J (1995) Effects of a large herbivorous gastropod on macrofauna communities in tropical seagrass meadows. Mar Ecol Prog Ser 121:125-137

Thom R, Miller B, Kennedy M (1995) Temporal patterns of grazers and vegetation in a temperate seagrass system. Aquat Bot 50:201-205

Tunberg BG, Nelson WG, Smith G (1994) Population ecology of Pagurus maclaughlinae Garcia-Gomez (Decapoda: Anomura: Paguridae) in the Indian River Lagoon, Florida. J Crustac Biol 14:686-699

Valentine JF, Heck KLJ (1991) The role of sea urchin grazing in regulating subtropical seagrass meadows: evidence from field manipulations in the northern Gulf of Mexico. J Exp Mar Biol Ecol 154:215-230

Vermaat J, Verhagen F (1996) Seasonal variation in the intertidal seagrass Zostera noltii Hornem.: coupling demographic and physiological patterns. Aquat Bot 52:259-281

Webb W, Newton M, Starr D (1974) Carbon dioxide exchange of Alnus rubra: a mathematical model. Oecologia 17: 281-291

Zieman JC, Wetzel RG (1980) Productivity in seagrasses: methods and rates. In: Phillips R, McRoy C (eds) Hand-

Editorial responsibility: Otto Kinne (Editor),

Oldendorf/Luhe, Germany book of seagrass biology: an ecosystem perspective. Garland Press, New York, p 87-116

Zimmerman RC, Kremer JN (1984) Episodic nutrient supply to a kelp forest ecosystem in southern California. J Mar Res 42:591-604

Zimmerman RC, SooHoo JB, Kremer JN, D'Argenio DZD (1987) Evaluation of variance approximation techniques for non-linear photosynthesis-irradiance models. Mar Biol 95:209-215

Zimmerman RC, Smith RD, Alberte RS (1989) Thermal acclimation and whole plant carbon balance in Zostera marina L. (eelgrass). J Exp Mar Biol Ecol 130:93-109

Zimmerman RC, Reguzzoni JL, Wyllie-Echeverria S, Josselyn M, Alberte RS (1991) Assessment of environmental suitability for growth of Zostera marina L. (eelgrass) in San Francisco Bay. Aquat Bot 39:353-366

Zimmerman RC, Cabello-Pasini, Alberte RS (1994) Modeling daily production of aquatic macrophytes from irradiance measurements: a comparative analysis. Mar Ecol Prog Ser 114:185-196

Zimmerman RC, Kohrs DG, Steller DL, Alberte R (1995a) Sucrose partitioning in Zostera marina L. in relation to photosynthesis and the daily light-dark cycle. Plant Physiol (Rockville, MD) 108:1665-1671

Zimmerman RC, Reguzzoni JL, Alberte RS (1995b) Eelgrass (Zostera marina L.) transplants in San Francisco Bay: role of light availability on metabolism, growth and survival. Aquat Bot 51:67-86

Zimmerman RC, Kohrs D, Alberte R (1996) Top-down impact through a bottom-up mechanism: the effect of limpet grazing on growth, productivity and carbon allocation of Zostera marina. Oecologia 107:560-567

Zimmerman RC, Kohrs D, Steller D, Alberte R (1997) Impacts of $\mathrm{CO}_{2}$-enrichment on productivity and light requirements of eelgrass. Plant Physiol (Rockville, MD) 115:599-607

Submitted: August 23, 1999; Accepted: February 23, 2001 Proofs received from author(s): July 25, 2001 